\title{
SUPPLY OPTIMIZATION OF OBJECTS AND NATURAL TOURIST ATTRACTIONS IN SITU GUNUNG, GUNUNG GEDE PANGRANGO NATIONAL PARK
}

\author{
ICHA AGUSTINA*) AND SAMBAS BASUNI \\ Department of Forest Resources Conservation and Ecotourism, Faculty of Forestry, IPB Campus Dramaga, Bogor \\ 16680, Indonesia \\ *Email: icha.agt@gmail.com
}

Accepted December 01, 2020/Approved February 15, 2021

\begin{abstract}
Situ Gunung Natural Tourism area as part of Gunung Gede Pangrango Natural Park utilization zone is a popular natural tourism destination. Therefore, the assessment on objects and attraction natural tourism attraction of Situ Gunung (ODTWASG) based on the satisfaction of management as the supply and visitors as the demand is essential to identify object and nature attraction that ecologically, socially, and economically need to be improved or maintained by the managers. The assessment results data were then processed and analyzed by using conformity scale method and Importance Performance Analysis (IPA). The results showed that there was one unsatisfying attribute on both parties in economic scale, i.e., the making of suspension bridge. Besides, there were two attributes of economic ODTWASG that have not been managed optimally. Thus, it has not contributed to customer satisfaction, which were food and beverages prices at the food court as well as water tourism object entrance fee. Therefore, ODTWASG supply optimization could focus on these two economic attributes; first, setting and adjusting the attribute of food and beverages prices, and second, improving water tourism quality.
\end{abstract}

Key words: Importance Performance Analysis (IPA), satisfaction, supply and demand

\section{INTRODUCTION}

Management of National Park in accordance with the provisions of clause 32 Law No. 5 of 1990 concerning Conservation of Natural Resources and Ecosystems, states that the national parks area were managed with zoning system consisting of core zone, utilisation zone, and other zones as required. Furthermore, clause 18 of Government Regulation (PP) No. 28 of 2011 jo. PP No. 108 of 2015 concerning Management of Nature Reserves and Nature Conservation Areas, states that zoning management in national parks includes (a) the core zone; (b) jungle zone; (c) utilization zone; and / or (d) other zones as required. It is further explained in PP No. 36 of 2010 that the utilization-zone is part of a national park which is designated for natural tourism and tourist visits. Based on this, Situ Gunung was included in the utilization zone of Gunung Gede Pangrango National Park which was used as a natural tourism destination.

The question in this research was "whether the management of natural tourism objects and attractions (ODTWA), including the provision of the facilities, has been done optimally and based on the concept of sustainable tourism development?" Thus, it is necessary to evaluate the satisfaction of objects and natural tourism attractions in the Situ Gunung Natural Tourism Area (KWASG) to find out which attributes the performance needs to be improved.

\section{RESEARCH METHOD}

This research was conducted in Situ Gunung Nature Tourism Area, Gunung Gede Pangrango National Park, West Java. The data collection method used is the same as the method used by Slamet and Fadjarwati (2020), which were the respondents were divided into two groups, namely management respondents and visitor respondents. Management respondents were key informants (regional section chief, head of the resort, forest ranger, and forest ecosystem controllers) and the management respondent from the private sector represented by the PT Fontis Aqua Vivam. Furthermore, respondents from the visitor' $\mathrm{s}$ side were selected based on purposive convinience sampling method, namely visitors to the Situ Gunung area in the research period who were adults and were willing to be interviewed and/ or filled out the questionnaire. In addition, to obtain additional data, literature studies were conducted to obtain supporting data such as the general conditions of the research location (Effendi 2014).

The assessment was carried out based on satisfaction of managers and visitors representing supply and demand side respectively for the three main dimensions of sustainable tourism as stated in The Sustainable Tourism Charter (1995) in Haryanto (2014) that was economic aspects, ecological aspects and social aspects. Economic aspect assessments was carried out by assessing whether tourism objects, activities and facilities were gave economically satisfaction. Ecological aspect assessments was carried out by assessing whether 
tourism objects, activities and facilities were gave ecologically satisfaction (environmentally friendly). Meanwhile the social aspect assessments was carried out by assessing whether tourism objects, activities and facilities were gave socially satisfaction.

Assessment attributes were determined based on the predetermined object of assessment. The objects in this study were similar to the object of research conducted by Slamet and Fadjarwati (2020), which were related to facilities and other objects that were assets of the area that can be optimized for performance by the manager through evaluation and assessment results by research subjects (respondents) to increase the comfort and satisfaction of visitors. Assessment result data that had been collected was processed using MS. Excel. Supplydemand analysis was conducted by measuring the level of suitability of the answers between managers and visitors and analysis using the Importance Performance Analysis (IPA) method. Supply-demand analysis is also used by Fanggidae and Bere (2020), to measure the level of visitor satisfaction towards management' $s$ performance in improving the quality of tourism facilities, and Karsudi et. al (2010) to examine the prospects for ecotourism development. The level of conformity was calculated using the following formula (Santoso 2014):

$$
T k i=\frac{X i}{Y i} \times 100 \%
$$

Explanation

Tki = Level of conformity

$\mathrm{Xi} \quad=$ Visitor assessment score

$\mathrm{Yi}=$ Manager assessment score
Sukardi and Cholidis (2006) stated that if the level of conformity is close to $100 \%$ or above the average, it can be concluded that the level of conformity is good or "appropriate". The range of conformity level categories based on the calculation results shown in Table 1 .

Table 1 Categorization of performance suitability.

\begin{tabular}{lc}
\hline Level of conformity (\%) & Category \\
\hline $0-44$ & Not Appropriate \\
$45-64$ & Less Appropriate \\
$65-84$ & Quite Appropriate \\
$85-100$ & Appropriate \\
$>100$ & Very Appropriate \\
\hline
\end{tabular}

Source : Martilla dan James 1977

According to Lai and Hitchcock (2016) IPA is a popular method for analyzing the satisfaction and performance of in the tourism sector. Rangkuti (2002), stated that the IPA method is used to measure the level of importance of a variable and relate it to the satisfaction felt by users. The results of the assessment that are entered into the IPA Cartesian diagram are the average value for each variable, which is calculated by the formula :

$$
\bar{X}=\frac{\sum x i}{n}
$$

Explanation :

$\bar{X}:$ The average value of the respondents' assessment

$\sum x \mathrm{i}$ : Total value of all respondents

$\mathrm{n}$ : Total number of respondents

The results of these calculations are then plotted into a cartesian diagram so that it occupies one of the four quadrants as shown in Figure 1.

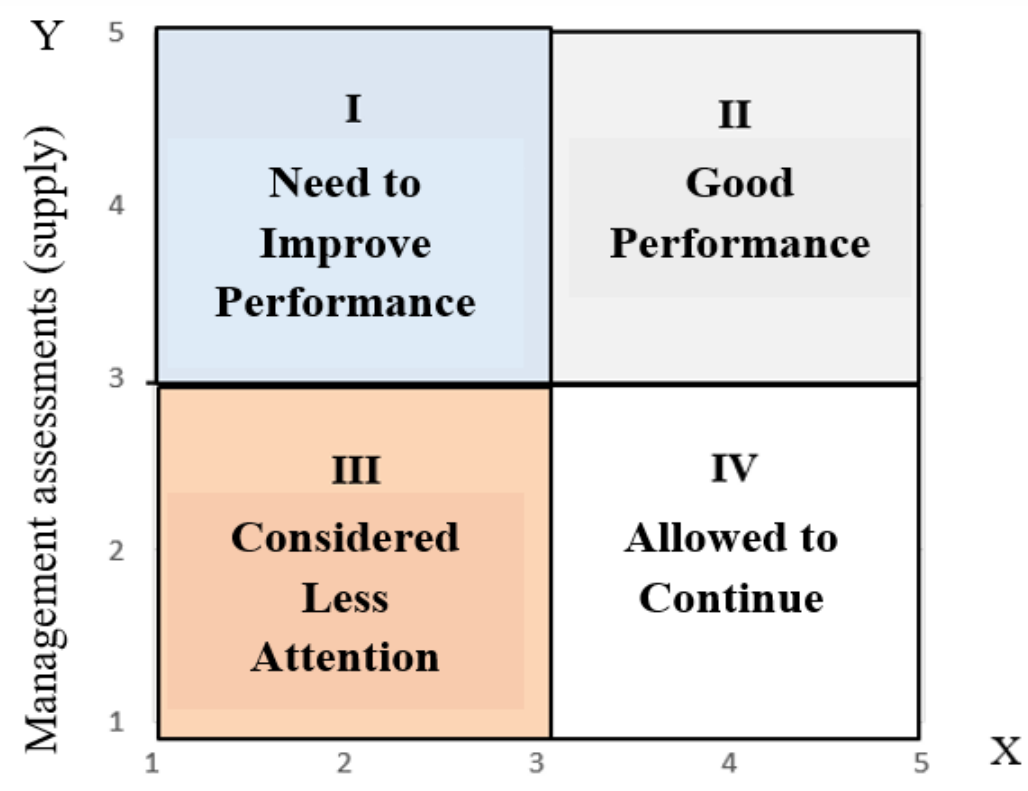

\section{Visitor assessments (demand)}

Figure 1 IPA diagram of supply-demand facilities and tourism facilities in Situ Gunung natural tourism area 
The secant line separating the boundaries between the quadrants is determined based on the quadrant approach centered on the scale (Martilla and James 1977). The interpretation of each quadrant in the IPA Cartesian diagram is as follows (Rangkuti 2002):

- Quadrant I, The performance of variables included in this quadrant should be improved immediately.

- Quadrant II, The variables included in this quadrant have provided satisfaction to the demand side due to the efforts made by the supply side thus their performance needs to be maintained.

- Quadrant III, The variables in this quadrant are considered as variables that are not paid attention by the management so that they provide low satisfaction for visitors.

- Quadrant $I V$, The management of variables in this quadrant can be allowed to continue as how it has been done although not yet satisfying to the manager, it was enough to gave satisfaction to visitors.

The IPA method had advantages over other methods, namely the IPA method was flexible enough to be applied in various fields, the procedure of the method used is quite simple, policy making to determine priority activities can be done easily with limited resources (Isfanari et al. 2011).

\section{RESULT AND DISCUSSION}

\section{General Condition of KWASG}

Based on the Decree of the Minister of Forestry No / .174 / Kpts-II / 2003 dated June 10th 2003 Situ Gunung was designated as one of the intensive use zones of Gunung Gede Pangrango National Park. Currently, the management of the Situ Gunung Nature Tourism Area (KWASG) is carried out by a private parties, namely PT Fontis Aqua Vivam, with an permitted management area of 102.76 hectares using a Business Permit for the Provision of Natural Tourism Facilities (IUPSWA) based on the decree of the Head of the Investment Coordinating Board with a SK number. 2/ 1 / KLHK / 2020 (Asad D July 16th 2020, pers com).

The number of female visitor respondents was higher than male respondents, with the percentage of $51 \%$. Age category of respondents with the highest number of respondents were adolescents aged between 12-25 years old with a percentage reaching $74 \%$ and the smallest percentage of $9 \%$ of the total respondents were older aged between 46-65 years old. This shows that the older (46-65 years old) group tend to avoid natural tourism activities that can be exhausting due to declining physical abilities (Marpaung 2002).

Most of the respondents were high school graduates, with the percentage of $80 \%$, there were no respondents with the education level of elementary school or junior high school. Most of the respondents' occupations were students with the percentage of $60 \%$ of the total respondents. Karsudi et al. (2010) stated that the determination of tourism objects to be visited by tourist is also influenced by education level where tourists with higher education tend to choose tourism objects that contain educational elements in addition to recreation. As many as $66 \%$ of the total respondents stated that their main motivation to visit KWASG was for recreation, while other motivations were for education, research and work. Forty percent $(40 \%)$ of the respondents in this study were visitors who had visited the KWASG 4th times or more. Furthermore, 34\% of respondents were respondents who had visited the KWASG for the first time, and the rest were visitors with second and third visits.

\section{Supply-Demand Analysis}

Supply-demand analysis is an analysis carried out by comparing the assessment of the satisfaction level of the demand side with offer provided by the supply side.

\section{a. IPA Natural Tourism Objects and Attractions (ODTWA) KWASG}

Based on research conducted by Darsono (2015), Hermawan (2017), and Diarta and Sarjana (2020) regarding the influence of the attributes of tourism attractions and services on tourist satisfaction, it is stated that tourism site attractiveness is one of the factors that determines visitor satisfaction and loyalty towards a tourism destination which consequently determines the repeat visits from a visitor. There were 19 attributes of ODTWA, that is attributes of (1) forests, (2) lakes, (3) waterfalls, (4) suspension bridges, (5) crossing bridges, (6) Sundanese theater, (7) welcoming food and drink, (8) food court, (9) bridges between objects, (10) footpaths, (11) taking pictures, (12) and water tourism (boating), (13) parking lots,(14) Toilets, (15) Prayer rooms, (16) trash cans, (17) ticketing, (18) access to tourism area, and (19) access within the tourism area. The results of the IPA analysis for the all attributes of KWASG ODTWA attributes are presented in Figure 2.

Figure 2 shows that all the attribute values of tourism objects and attractions as well as facilities and natural tourism activities in KWASG are in quadrant II. This means the attributes of ODTWA are managed fairly well with relatively high ratings by the management and the visitors. Therefore, the current management of the KWASG ODTWA needs to be maintained. The results of the calculation of the conformity level of the ODTWA assessment by visitors and managers reached $89 \%$, which means that the assessments made by the managers and the visitors were categorized as "appropriate". The ODTWA with the highest ratings from visitors and managers can be said to be the most satisfying ODTWA.

\section{b. IPA Ecological Aspects}

The results of the IPA analysis for the ecological aspects attributes are presented in Figure 3. Figure 3 shows that attributes the authenticity of the (1) forest certainty, (2) cleanliness of the lake, (3) cleanliness of 
waterfalls, (4) placement of suspension bridges, (5) suspension bridge materials, (6) placement of bridges between objects tourism, (7) bridge materials connecting objects, (8) parking lots enviromentally friendly, (9) footpaths, (10) placement and building materials for toilets, (11) availability of water in toilets, (12) placement and building materials for prayer rooms, (13) cleanliness of prayer rooms, (14) placement and materials for trash bins, (15) food court, (16) welcoming food and drink stands, (17) placement Sundanese theater, (18) beauty of tourism objects as photo backdrops, (19) bridge crossing activities, (20) water tourism, (21) the naturalness of the tourism attraction,(22) placement counters, (23) road conditions to KWASG, and (24) road conditions in KWASG received a relatively high and satisfactory rating from the visitors for the performance that has been done by the management which were all in quadrant II. The average suitability level of all aspects reached $90 \%$ and was included in the "appropriate" category. An assessment of tourism objects and attractions as well as facilities and infrastructure based on ecological aspects is necessary to maximize the utilization of KWASG potential through a development plan based on ecotourism concepts (Putri et al. 2014). Based on the findings of Purnamasari et al. (2005) in their research, many visitors to tourism areas prefer natural forms of facilities, so that ecological aspect also needs to be included into consideration in the development of facilities and ODTWA.

\section{c. IPA Social Aspects}

The social aspects assessed in this study related to the social hospitality of all the attributes of the assessment of the needs of visitors in general and the services provided by the management for visitors. The results of the IPA analysis of social aspect attributes are presented in Figure 4.

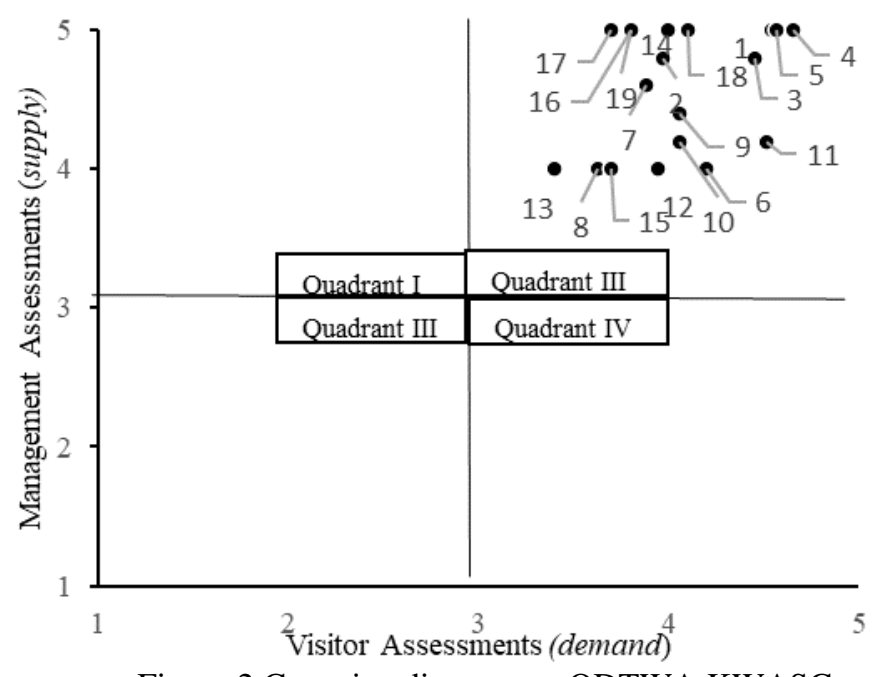

Figure 2 Cartesian diagram on ODTWA KWASG

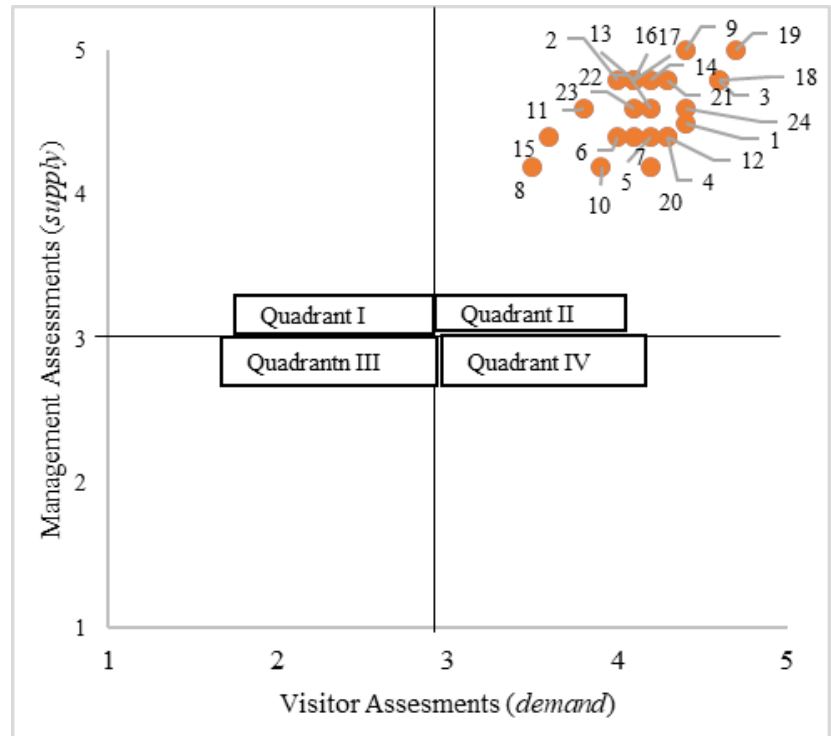

Figure 3 Cartesian diagram on ecological aspect 
Figure 4 shows that the attributes of the assessment on social aspect, that were, (1) tranquility of the forest, (2) lake security, (3) waterfall safety, (4) ease of use of suspension bridges, ( 5) ease of use bridges between tourism objects, (6) parking lots, (7) walking paths, (8) separate toilets for men and women, (9) safe toilets, (10) prayer rooms, (11) prayer rooms security, (12) trash cans, (13) food court, (14) orderly welcoming food and drink stands, (15) Sundanese theater, (16) freedom to take pictures of tourism objects, (17) orderly crossing a suspension bridge, (18) water tourism safety, (19) ticket counters, (20) friendly service, (21) access to KWASG with 4-wheeled vehicles, (22) access to KWASG by public transportation, (23) and road signs. All the attributes in quadrant II indicate that all these attributes receive a relatively high rating. In other words, the level of conformity of visitors and managers assessments is in the "appropriate" category with a suitability level of $91 \%$.
A well-managed social aspect will give visitors nice experience and impression. The quality of the tourism experience can be maintained or even improved by carrying out tourism management through service management that takes into account the comfort and needs of visitors (Manning 2007). Tjiptono and Chandra (2011) argued that efforts to meet customer needs and delivery accuracy in order to match customer expectations are the focus for determining service quality. Improving service quality can increase the competitiveness of a service business thus it is able to compete with other competitors in similar fields.

\section{d. IPA Economic Aspects}

The economic aspect in this study was related to the costs required to travel to KWASG and other costs that were expected to be incurred while visiting KWASG. Assessment related to economic aspect by the management and the KWASG visitors shown in Figure 5.

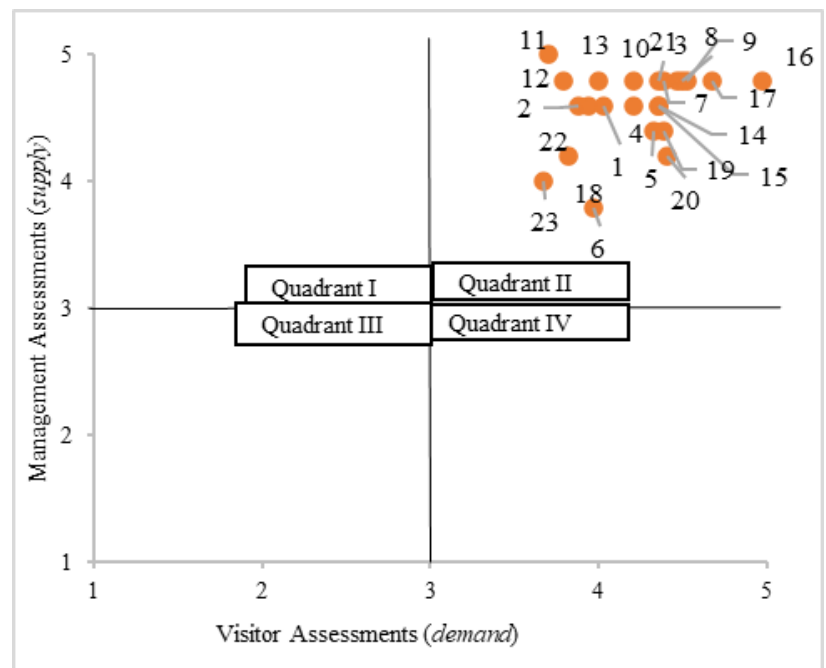

Figure 4 Cartesian diagram on social aspect

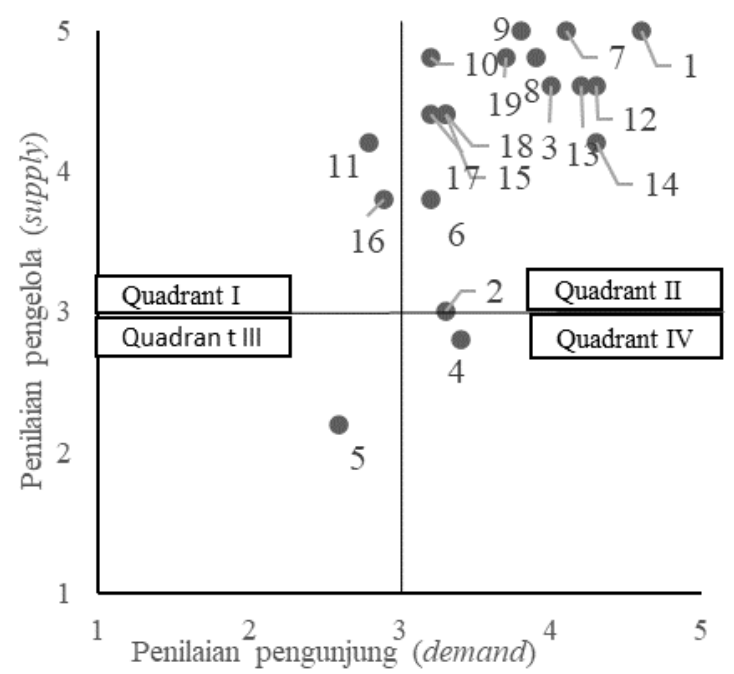

Figure 5 Cartesian diagram on economic aspect 
Based on Figure 5, the position of the attributes of (11) similar food and beverage prices in the food court and (16) the cost of water tourism are in quadrant I, which means that these two attributes received a relatively high rating from the management, in contrast with a low rating given by the visitors. Prices for similar food and beverages sold in the food court should be standardized. Meanwhile, the cost for enjoying water tourism activities such as riding a raft or water biking in Situ Gunung Lake, which cost $\pm \mathrm{Rp} 25,000$ / person was rated too expensive by visitors. This is because the conditions of the rafts, water bikes and equipments to ensure the safety of visitors are inadequate. In research conducted by Hermawan (2017), it is stated that increasing tourism safety will increase the number of tourist visits to a tourism destination. This is in line with Chiang (2000) statement which stated that tourists will consider safety guarantees when choosing tourism destinations to visit. Managers need to improve performance related to the safety of water tourism activities such as paying attention to the condition of boats, rafts and water bikes by checking and maintaining them regularly and providing lifevests for visitors engaging in these water tourism activities. Moreover, it is obligatory for tourism managers to provide protection against the risk of tourism accidents to visitors (Suharto 2016). The attribute of the price of similar food and beverages in the food court and the cost of water tourism were two attribute that need to be optimized to increase visitor satisfaction.

Furthermore, in quadrant II there are attributes of (1) the cost of enjoying forest shade, (2) the cost of water tourism, (3) the cost of enjoying waterfalls, (6) parking fees, (7) the cost of use of paths, (8) fees for using toilets, (9) the cost of use of religious equipment, (10) the cost of transporting waste, (12) the cost of enjoying a welcoming food and drink, (13) the cost of watching Sundanese theater, (14) the cost of taking selfies, the cost of (15) crossing the bridge, (17) the price of entrance tickets to the area, (18) the cost of travel to KWASG, (19) and the cost of access within the area. Attributes contained in quadrant II are attributes that are deemed appropriate for management to be maintained because they have received relatively high ratings from both the managers and the visitors. Sulistiyana et al. (2015) stated in their research that price is a variable that has the most dominant influence on consumer satisfaction where consumers will feel satisfied if the price offered is affordable and in accordance with what visitors expect. Irawan and Handi (2002) stated that for sensitive consumers, low prices are usually an important source of satisfaction due to the perception that it gives more value to the money that has been spent. However, this does not apply to consumers who are not sensitive because of the assumption that it is better to choose a relative ly more expensive price with higher quality products than low prices with the undesired products.
Figure 5 also shows that in quadrant III there is one attribute, that is the attribute of (5) the cost of building a bridge and one attribute in quadrant IV, namely attribute (4) the cost of building a connecting bridge between tourist objects. Attributes that are in quadrant III are attributes that received relatively low ratings from the managers and the visitors. Meanwhile the attribute in quadran IV was attribute that recieved relatively low ratings from the manager but had given satisfaction to the visitors so that current management can be continued as had been done. Those attributes assesses the costs spent on making suspension bridges and bridges between objects in KWASG. The cost is relatively expensive because the materials used are semi-permanent materials that are environmentally friendly with high quality. The construction of the bridges use ironwood with a manual working process without heavy equipment to reduce the negative impacts towards environment thus it requires relatively expensive costs (Asad D July $16^{\text {th }} 2020$, pers com).

Managers are willing to pay quite expensive costs for the construction of tourism facilities and infrastructure at KWASG including a suspension bridge as an initial investment in the tourism business. According to Rose (2005) in Nurhayati (2016), investment is an expenditure on capital goods at the beginning of a business with expectation to giant benefits in the future. The investment made by the management is a long-term investment in the tourism sector, especially in terms of providing facilities and infrastructure and tourism destinations for tourism development (Nurhayati 2016). The business permit owned by PT Fontis Aqua Vivam as a private party managing the utilization zone of the Gunung Gede Pangrango National Park area is a Business Permit for Nature Tourism Facilities Providers (IUPSWA) with a period of 55 years and can be extended up to 20 years for a further period and can be extended. for another period based on clause 35 in Regulating of Ministry of Forestry No. P.48 / Menhut-II / 2010. The average number of visitors who came to KWASG ranged from 19,590-41,568 people per month. The estimated gross income obtained by the management from ticket sales of tour packages which cost IDR 50,000/ person can reach IDR 2,078,400,000/ month. Thus, the investment made at the beginning of the development will greatly affect the revenues gain by the tourism destination management in the future. The average value of the suitability level of economic aspects attributes reaches $85 \%$ and is included in the "appropriate" category.

\section{e. IPA All Aspects}

ODTWA, ecological aspects, social aspects, and economic aspects that had been assessed as a whole were then mapped back into quadrants using the IPA method to determine the overall value of each aspect that is the assessment variable in this study. All aspects of the 
assessment, that is ODTWA (1), ecological aspect (2), social aspect (3), and economic aspects (4) are in quadrant II. This means, overall, all aspects of the assessment in this study received a relatively high rating from the visitors (demand) and the management (supply). The results of all aspects of the IPA analysis shown in Figure 6.

Based on Figure 6, the variables in quadrant II indicate that the level of satisfaction felt by visitors to the performance of the management is satisfactory and proportional to what the management has done to improve their performance. The performance carried out by the management can be said to be a fine performance and deserves to be maintained. The level of conformity in the assessment of all these aspects reaches $89 \%$ and can be said to be "appropriate".

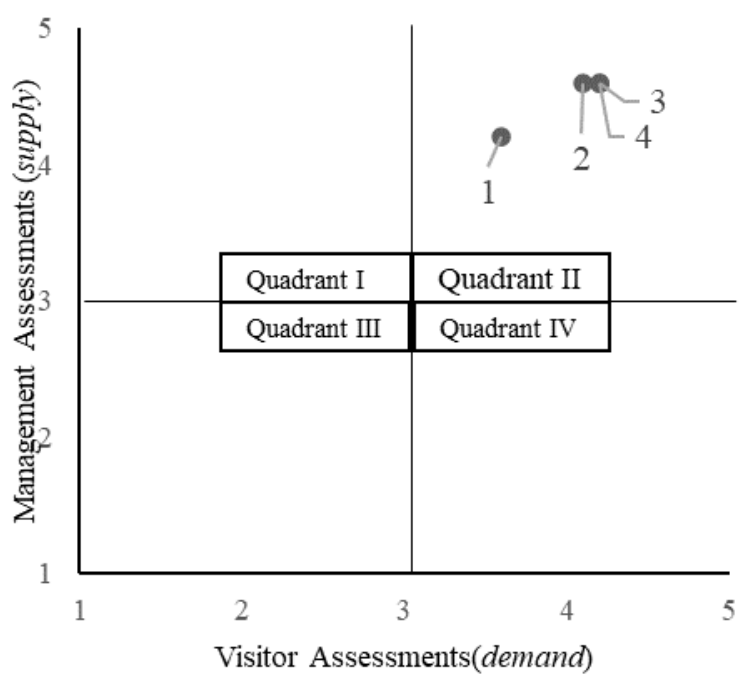

Figure 6 Cartesian diagram in all aspects of the assessment

\section{CONCLUSION}

The result showed that all the attributes of the ecological and social aspects of ODTWASG had been managed optimally and had provided ecological and social satisfaction to both parties (supplier and demand) so that the management performance needs to be maintained. In the economic aspects there was one attribute that was unsatisfactory to both parties, namely the cost of making the suspension bridge. However, from the manager' $s$ point of view this could be interpreted as " ignored" as it is a long term investment. However, there were two attributes of the economic aspects of ODTWASG that had not been managed optimally and have not provided satisfaction to visitors, namely the price of similar food and beverages in food courts.

\section{REFERENCES}

Chiang LC. 2000. Strategies for safety and security in tourism: a conceptual framework for the Singapore hotel industry. Journal of Tourism Studies. 11(2): 44-52.

Darsono R. 2015. Pengaruh kualitas daya tarik wisata terhadap tingkat kepuasan wisatawan, studi kasus di Waduk Jatiluhur-Kabupaten Purwakarta. Jurnal Nasional Pariwisata. 5(1): 14-22.

Diarta IKS, Sarjana IM. 2020. Pengaruh atribut dan kualitas layanan terhadap kepuasan pengunjung daya tarik wisata pertanian subak di Kota Denpasar Bali. Media Konservasi. 25(2): 113-123.

Effendi S. 2014. Metode Penelitian Survei. Yogyakarta: LP3ES.

Fanggidae RPC, Bere MLR. 2020. Pengukuran tingkat kepuasan wisatawan terhadap fasilitas wisata di Pantai Lasiana. Jurnal Manajemen Aset Infrastruktur \& Fasilitas. 4(1): 53-66.

Haryanto JT. 2014. Model pengembangan pariwisata dalam mendukung kemandirian ekonomi daerah studi kasus Provinsi DIY. Jurnal Kawistara. 4(3): 271-286.

Hermawan H. 2017. Pengaruh daya tarik wisata, keselamatan, dan sarana wisata terhadap kepuasan serta dampaknya terhadap loyalitas wisatawan. Jurnal Media Wisata. 15(1): 562-577.

Irawan, Handi. 2002. 10 Prinsip kepuasan pelanggan. Jakarta: PT Elex Media Komputindo.

Isfanari, Sulistio, Wicaksono. 2011. Kajian karakteristik angkutan ojek sepeda dan cidomo di Kota Mataram. Jurnal Rekayasa Sipil. 5(2): 84-94. 
Karsudi, Soekmadi R, Kartodiharjo H. 2010. Strategi pengembangan ekowisata di Kabupaten Kepulauan Yapen Provinsi Papua. Jurnal Manajemen Hutan Tropika. 16(3):148-154.

Lai I, Hitchcock M. 2016. A comparison of service quality attributes for stand-alone and resort-based luxury hotels in Macau: 3-dimensional importance performance analysis. Tourism Management. 55:139-159.

Manning RE. 2007. Parks and Carrying Capacity: Commons Without Tragedy. Washington DC: Island Press.

Marpaung H. 2002. Pengantar Kepariwisataan. Bandung: Alfabeta.

Martilla JA, James JC. 1977. Importance-performance analysis. The Journal of Marketing. 41(1):77-79.

Nurhayati. 2016. Analisis investasi sektor pariwisata oleh pemerintah daerah Kota Batam tahun 2014. Jurnal Dimensi. 5(2):1-22.

Purnamasari Q, Indrawan A, Muntasib EKSH. 2005. Kajian pengembangan produk wisata alam berbasis ekologi di wilayah Wana Wisata Curug Cilember (WWC), Kabupaten Bogor. Jurnal Manajemen Hutan Tropika. 11(1):14-30.

Putri MN, Riyono JN, Herawatiningsih R.2014. Penilaian objek dan daya tarik riam asam telogah di Kecamatan Noyan Kabupaten Sanggau untuk Wisata Alam. Jurnal Hutan Lestari. 2(2):357-364 Rangkuti F. 2002. Measuring Costumer Satisfaction. Jakarta: PT Gramedia Utama.

Santoso S. 2014. Panduan Lengkap SPSS Versi 20. Jakarta: Gramedia Pustaka.

Slamet FF, Fadjarwati N. 2020. Evaluasi kinerja aset fasilitas wisata domba di Kabupaten Garut. Jurnal Manajemen Aset Infrastruktur \& Fasilitas. 2(3):183-194.

Suharto. 2016. Studi tentang keamanan dan keselamatan pengunjung hubungannya dengan citra destinasi (studi kasus Gembira Loka Zoo). Jurnal Media Wisata. 14(1):287-304.

Sukardi, Cholidis C. 2006. Analisis tingkat kepuasan pelanggan terhadap produk corned pronas produksi PT CIP, Denpasar, Bali. Jurnal Teknologi Industri Pertanian. 18(2):106-117.

Sulistiyana RT, Hamid D, Azizah DF. 2015. Pengaruh fasilitas wisata dan harga terhadap kepuasan konsumen (studi pada Museum Satwa). Jurnal Administrasi Bisnis. 25(1):1-9.

Tjiptono J, Chandra G. 2011. Service Quality Statisfaction. Yogyakarta: ANDI. 